\title{
Contract Gangs: Race, Gender and Vulnerability
}

\author{
Heather Goodall \\ University of Technology Sydney
}

\begin{abstract}
While violence directed at Indian students in Australian cities has been highlighted in the Indian and Australian press, far less attention has been paid to the violence directed at Indians in rural areas. This has most often involved Indians employed in contract labour in seasonal industries like fruit or vegetable picking. This article reviews various media accounts, both urban and rural, of violence directed at Indians from 2009 to 2012. It draws attention to the far longer history of labour exploitation which has taken place in rural and urban Australia in contract labour conditions and the particular invisibility of rural settings for such violence. Racial minorities, like Aboriginal and Chinese workers, and women in agriculture and domestic work, have seldom had adequate power to respond industrially or politically. This means that in the past, these groups been particularly vulnerable to such structural exploitation. The paper concludes by calling for greater attention not only to the particular vulnerability of Indians in rural settings but to the wider presence of racialised and gendered exploitation enabled by contract labour structures.
\end{abstract}

The vulnerability of international students in casual employment has been powerfully exposed in recent years. Time and again, the city has been shown to be a site of danger for Indian students. This paper will argue, however, that despite the specific urban focus of recent political concerns, the attacks on Indian students are consistent with a long term structural vulnerability for casual and contract labourers, particularly those where racialisation of recruitment has occurred. This vulnerability is as true in rural areas - and perhaps of even greater concern - as it is in urban areas. While anecdotes suggest these conditions are widespread, it is unlikely that substantial empirical evidence will emerge to show broad trends, because by definition all involved in the casual and contract labour Cosmopolitan Civil Societies Journal, Vol.7, No.3, 2015 
arrangements described below have a strong interest in keeping very quiet about what is going on. So this paper can at most present individual case studies - each of which indicate that other occurrences of such abuses are occurring - in order to sketch out the issues. As historical precedent among other racialised groups of labourers has been documented in varying ways, we can at least identify patterns of vulnerability which need - in the light of media and union investigations - to be considered to be of as much concern as racialised urban violence.

In 2013, the United Voice union released an excellent, meticulously-documented report on international students in contract cleaning teams in Melbourne's CBD. More than half of those CBD cleaners are South Asians from India, Sri Lanka and Bangladesh with a few nonIndian but still non-European workers with a background in Colombia. This searing report documents the conditions of poverty faced by many South Asian students in a country like Australia where the cost of living is high, which leads them to seek extra employment, particularly outside normal business hours and most class times. Contract cleaning seems to fulfill many of their needs. Once under contract, however, students feel trapped because their student visas and residency conditions are so limited they fear they will face expulsion and deportation if they admit to earning over the narrow study visa limits or if they antagonise their contractor/managers. They are left unable to speak out or defend themselves despite finding themselves being forced to work in exploited conditions where they are subject to verbal, physical and at times sexual abuse.

This exposé of contractual working conditions in urban Melbourne points to the systematic exploitation of international students - and particularly South Asians, who have fewer family resources on which to rely when compared to students from East Asia who are in general more solidly middle class. All foreign students - away from home and familiar structures are at risk and it is certainly likely that they are targeted because they have already been made to feel insecure by a range of prejudices that inhibit them from speaking out. The Union report focuses on urban conditions because this is where most contract cleaning companies operate to service the city's high density office and residential concentrations. This is also where most of the well-publicised attacks on Indian students took place because cities in Australia house far more tertiary institutions and far more students than rural areas. In Melbourne, just like other Australian cities, residential segregation has ensured that any national or racial groups are highly visible. The number of Indian students particularly has 
increased rapidly in Australia in the last 10 years, so the sudden expansion of their presence in such residential concentrations has been even more noticeable.

The focus on cities as sites of violence against Indians also seemed to be confirmed during the violent attacks in 2009 and 2010 because cities were where the most vocal response occurred. But the conditions highlighted in the United Voice report are not exceptional. The exploitation of workers through contract teams is a problem which faces Indian students in rural as well as urban areas. Anecdotally, this appears to have become a common experience for international students because they are likely to go to the few rural universities. The rural tertiary education providers, like Charles Sturt University, with numerous campus sites including Ballarat, Albury-Wodonga, Dubbo, Goulburn and Bathurst tend to rank low as preferred destinations for Anglo Australian students. So these institutions are very active in recruiting from overseas. The regions in the eastern states of Australia where agriculture and regular commercial harvesting occur have seen substantial settlement by incoming Indian migrants and temporary workers, as data on religious affiliation from the 2011 Census suggests. At the least, Indian students may be more interested in attending universities which have nearby resident Indian populations.

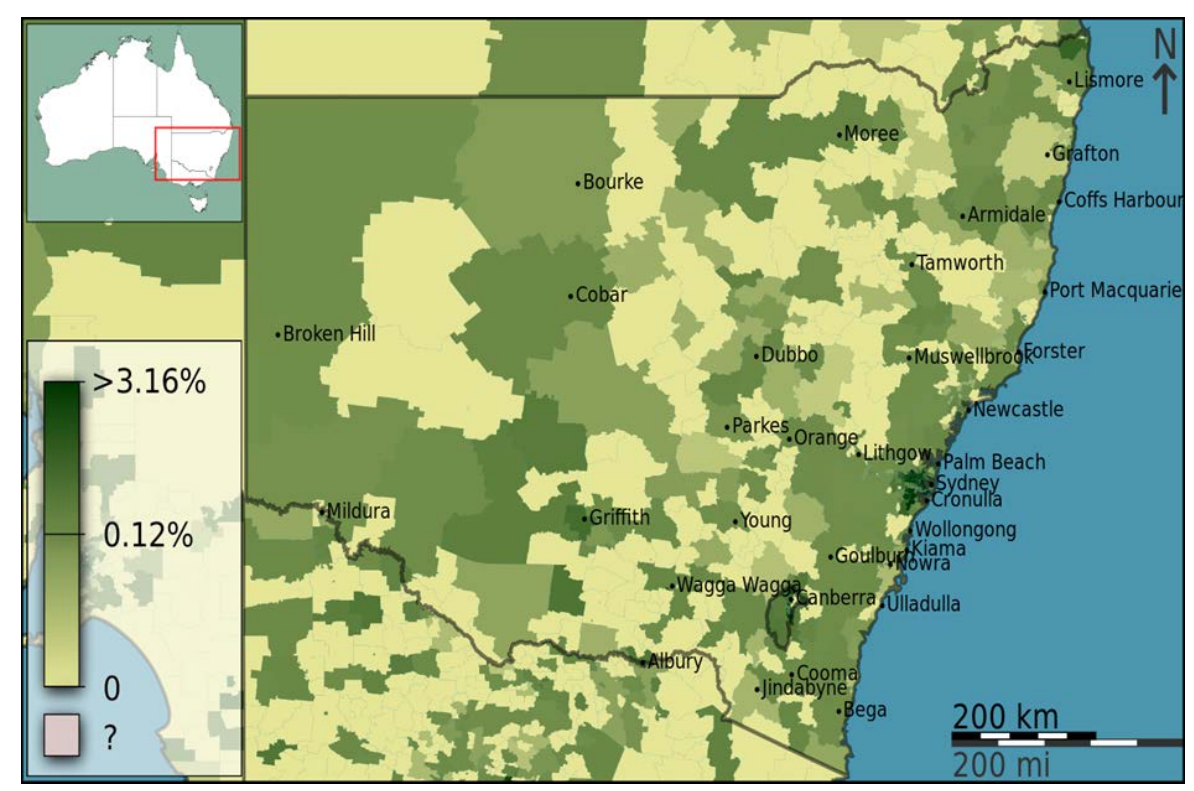

Map from Australian Bureau of Statistics 2011 census data: Shows proportionally high affiliation with Hinduism among populations in southwestern NSW and throughout the western edge of the arc of fruit and vegetable harvesting areas. ${ }^{1}$

\footnotetext{
${ }^{1}$ Hinduism Persons (field 2775) as a fraction of total persons, in New South Wales, Australia, according to the 2011 census. The map is divided into geographical subdivisions by Postal Area. This graphic uses data from the
} 
Once in Australia, however, students enrolled in such rurally-based universities and colleges find they are still faced with the high Australian cost of living - in fact high transport costs often make food and other goods more expensive in country towns than in the cities - but they have fewer opportunities than they would have in urban areas to earn additional cash to allow them to cope.

For these students trying to make ends meet, seasonal agricultural work organised in contract teams - often called 'gangs' - offers one of the few alternatives. Students from all backgrounds in urban universities have done this type of work during their holidays to generate cash in the past: both cotton chipping and fruit picking were common during my undergraduate days in the 1970s. Cotton is no longer 'chipped' of weeds - because of the increased use of chemical weed-killers. However, fruit picking and vegetable harvesting contract gangs continue to be the main source of the high farm labour needed seasonally in a rural environment like Australia in which most working class populations moved to urban areas in the 1950s where work was easier to come by. So workers for rural seasonal work like harvesting have to be gathered up from wherever they are and delivered to the farmer. This is done by contractors, who 'source' the labour, organise the workers, transport them, feed them, distribute pay to them and discipline them.

Although further research is required, there are significant similarities here with the patterns of recruitment and control in maritime conditions over the last 200 years (Ahuja 2006; Balachandran 2012; Broeze 1991; Rediker 2007).

Not only has the attention to urban areas distracted notice from rural conditions, but as well, the focus on students has unnecessarily narrowed the discussion about who is vulnerable. University students provide one source for this seasonal contract labour, but they often come to Australia with their families and those families members then become another source of labour. There are as well other marginalised and already-resident population groups who may also be 'sourced' for such ephemeral work, like recently settled refugees or Aboriginal workers. Yet another 'source' for such labour are workers brought temporarily from overseas on 475 or similar visas. This brings together the questions of the vulnerability of student 
labour including their families (for all of whom stipends and visas severely limit the amount of cash which can be earned) with the vulnerability of 457 and other 'special' employment visa workers, whose continued residency is entirely in the hands of their employers.

For a contract team, it is the contractor who is the effective employer. Even where 457 visa holders have been recruited more directly by farmers through agents, there are still middle men along the way and any movement into other work is likely to bring the worker into contact with a contractor to manage the process. This then places significant power into the hands of contractors. Recruitment of labour is often undertaken ethnically - so that the contractor will be from among the marginalised group but will have developed the skills and strategy - and found the entry capital - to establish him or herself as a company to do the recruiting, feeding, transporting and managing of labour which is then 'contracted' to the farmer. The contractor may speak the same language as the labourers if their common tongue is not English, giving the contractor the additional role - and power - of translating between the workers and the farmer who hires their labour. As one from among their community, the contractors may also be aware of cultural specificities and so, as a 'cultural broker' may be able to make the employment process more simple for the farmer. This may protect the workers from imposition but on the other hand, it may also make the contractor privy to the workers' fears, anxieties and vulnerabilities, particularly if there are visa irregularities involved, magnifying still further the power which the contractors might hold over 'their' workers.

A further risk for rural labourers is the extreme danger of most agricultural occupations, arising from largely unregulated situations ranging from using heavy and unfamiliar machinery to exposure to multiple toxic chemicals used as pesticides, herbicides and fertilisers. While at times the level of use of any one chemical might be controlled, the effects of exposure to combinations of these chemicals is seldom understood, let alone limited by Health and Safety regulations (ILO 1981-1985; Herde \& Lowe, 2013). Where agricultural workers are injured in any way during their employment in a contract team, there is often little provision for insurance and routine worker's compensation, even if the labourer were able to challenge the contractor and the farmer to pay the cost of treatment and care.

While these may be worst-case scenarios, there is little to protect workers if this is the way their relationship with the contractor works out. Seasonal workers are often represented 
poorly by unions, even where the Union is seeking to be available. Workers who are mobile and casual - and may not be fully comfortable in English or in the local employment rules are unlikely to seek out union support for their differences with the contractor.

The largest rural union, the Australian Workers Union, was aware before 2009 of the possibility of Indian students being exploited through work in rural contract teams and had been seeking to sign them on to cover them more effectively. Yet the major demonstrations by Indians against violence during 2009 had been in central Melbourne, so little attention had been directed towards rural work. Then in January 2010, violence against Indians became front page news due to two tragic murders. One was that of Ranjodh Singh in the fruitgrowing district near Griffith, NSW, a young man who was known to be a seasonal worker, and the other was that of Nitin Garg, the 21 year old year old accounting graduate who was stabbed to death as he crossed a Melbourne park alone to go to his evening shift job at a fast food restaurant. While both cases hit the headlines in both Australia and India, the case of Ranjodh Singh largely disappeared from Indian coverage a week later when three Indians, who were also involved in fruit picking, were charged with his murder. The stabbing death of Nitin Garg by unknown assailants remained on the front pages for some months, however, as did other cases of appalling violence against individual Indians in cities. Some was clearly associated with racist abuse while other instances were less clear - with perpetrators belonging to a range of ethnic and immigrant groups themselves and their violence often revealing the rising tensions among impoverished and similarly vulnerable populations. Attention remained firmly on the cities and the big populations of Indian students, which finally brought some much needed attention to both racism and also to the poor living conditions imposed on urban-based international students.

In the process, rural issues had slipped right off everyone's radar. Yet there are important and continuing issues which relate both to race relations and to labour conditions which have therefore also disappeared from view, despite their being most visible in the rural setting. The rural experiences of students were not well identified in the many front-page stories in either Australian or Indian newspapers during 2009 and 2010. Furthermore, the fact that many contractors may themselves have been Indian complicated the scenario further still: the accusations that attacks on Indian students were pure racism were harder to sustain when both the perpetrators and the victims were Indian. So the urban conflicts dominated the press in both Australia and India. But rural tensions eventually began to flare into visibility. 
The remainder of this paper will sketch out the parameters of these questions through three brief case studies of Indian rural experiences.

The first case is the murder of Pradeep Kumar, 33, who was said to have been abducted from the Mildura Library in September 2009, in the heart of the Riverina, the fruit-growing area of the western Murray River. He was murdered but his body was not found for 13 days and since October 2009, his death has remained unsolved. Little information was released about Mr Kumar other than that he had worked as a fruit picking labour contractor before his death and that his family came to Australia from the Punjab to claim his body and take it home. His death was reported but grabbed little attention among the more graphic accounts of bashings and threats which were occurring in Melbourne itself over these same months (ABC 2009, 2010, 2012). More suggestions about the climate in which he died would only become apparent in the course of the second case.

This second case was the gruesome murder of Ranjodh Singh, another young man from the Punjab who was a fruit picker, and had been employed by contractors to work on the surrounding fruit farms. Ranjodh had been tied hand and foot, had been stabbed many times and then set alight, apparently while still alive, and left to die beside a road outside of the town. He had come to Australia because his wife had been accepted to study Cookery in a TAFE College. His presence as a fruit picker highlights the difficult position in which families of students have been placed. Whereas Australian educational bodies expect people enrolled in first degrees or diplomas to be young and single, for Indians it is frequently the case that they already have partner and they need not only the companionship but the financial support which a husband or wife can bring to survive the high Australian cost of living while they study. So Ranjodh had gone fruit picking. But, like so many casual, contract fruit pickers, he had found himself being owed the money he should have been paid for his last job.

The important fact that this was a widespread experience was discussed at length by the Australian Workers' Union organiser for Griffith, Harry Goring, who spoke to the ABC and other media on a number of occasions about the circumstances of Ranjodh's death. His account of the conditions faced by casual fruit pickers in contract gangs opens up a grim picture of systematic exploitation, thefts and violence. 
The regional Riverina radio station of the Australian Broadcasting Corporation's rural network broadcast the following news item on 5 January, 2010 (ABC Riverina 2010), the day the story broke about the murder of Ranjodh Singh. This is the transcript of the news broadcast itself, read by the ABC announcer, with quotes from Goring included:

'Harry Goring from the Australian Workers Union says he has heard of unpaid labourers taking matters into their own hands.

"Over the last 12 months there's been two assaults around that area, people endeavouring to retrieve money for labour," he said. "I'm not saying for a moment that it's this with this man, but there have been a number of fracases in relation to Indian people pursuing certain individuals."

'Mr Goring says action is needed to ensure legal processes are followed by contractors. "From Centrelink to Immigration, Fair Work, Workcover, we all need to do a sustained effort to fix this problem," he said.

'Mr Goring says he and local MP Adrian Piccoli planned a forum of farmers and contractors four years ago to address the unscrupulous use of harvest labour, but it did not happen. He is urging farmers to ensure contractors are legitimate, saying he gets weekly complaints about wages being stolen.

Mr Goring says there has been a huge increase in contract labour, particularly Indian students, and many are being ripped off.

"It's a weekly occurrence. We don't hear about the one and twos that are happening. It only becomes sensational when a large group gets ripped off," he said.

"You and I will never know the amount of people who are lining up for payment, and as they're doling out the dollars, where they thought they were going to get $\$ 200$, they then have to barter and argue for a percentage of that amount.

"They arrive on our doorstep [in Griffith] without any plans, without accommodation and they are scooped up by so-called contractors."

The main national ABC Radio evening news program, $P M$, broadcast the following interview on 8 January, 2010 (ABC PM 2010) between its reporter, Lucy McNally and the AWU organiser, Harry Goring:

HARRY GORING: I'm certainly building on information that I've been given round and about in the paddocks. It is the unfortunate outcome of what has been an escalating occurrence of violence in this region in regard to contractors welching on paying the labour. 
LUCY MCNALLY: Contractors are the "middle men" who come onto a property and offer to take control of the labourers for farmers. The farmers pay the contractors, and the contractors pay the workers. But Mr Goring says many labourers are getting a bad deal.

HARRY GORING: They come up here without accommodation, without a job and they are scooped up by so-called contractors. The whole thing comes undone of course at the end when it comes to the time to be paid and either they're not paid what was agreed or not paid at all.

LUCY MCNALLY: Two weeks before Mr Singh's murder, five Indians allegedly committed a home invasion in Griffith, assaulting two men. Mr Goring says they were farm workers who didn't get the right pay and took matters into their own hands.

Reports of Goring's comments from both news programs were carried in the Times of India (5/1/10) and on the Indian news agency site Rediff.com (5/1/10) but there was little after that. On January 30, three people faced court in Wagga Wagga to be charged with Ranjodh's murder but all were Indians. (The Australian) They too were in the fruit industry, with two being fruit pickers like Ranjodh had been and the third being a contractor, who 'had worked in Griffith sourcing Indian labourers for local farms' (SMH 18/4/10). According to the police evidence at the committal hearing (SMH 18/4/10) the contractor had 'earned a reputation as a violent stand-over man who owed about $\$ 9000$ to his workers and had recently moved to Wagga Wagga after falling out with a farmer’. He was understood to have owed Ranjodh money for the last job. The two fruit pickers pleaded guilty to being accessories after the fact of murder, but the contractor went to trial, pleading not guilty. In the end, the case was dismissed due to the evidence against the contractor being no more than circumstantial.

This story does not fit easily into the narratives which were so prevalent in both Australian and Indian newspapers at the time, of violence against Indian students committed by white Australians motivated by racism. It was perhaps that reason which led to this story disappearing not only from the Indian newspapers but also from the Australian papers. Because what it shows is an even more persistent pattern of systematic exploitation of vulnerable workers in contract conditions and particularly in the agricultural industry.

The third case is, if possible, even more disturbing as it reflects a longer pattern of both intimidation and violence on the part of contractors, of collusion with contracting farmers and of inaction and indifference by police in rural areas. This was another case which received scant media attention in the Australian press and none at all, as far is it has been possible to 
see, in the Indian media. This was the case of the rape and sexual abuse of a series of Indian contract workers by a contractor or 'supervisor' in this same area, culminating, after a series of failed attempts by women to press criminal charges, in the successful prosecution of a civil action against the contractor by one determined Indian woman who had been one of his rape victims.

This case reflects the particular vulnerabilities of Indian women, whether they come to Australia as students, as wives of students or as agricultural workers on 457 visas. A history of gendered racism in Australia, as many Aboriginal women have highlighted, has meant that all women of colour are subject, on the one hand, to sexual violence or the threat of it and on the other hand, to official disinterest and failures to pursue justice on their behalf (Weaver 2009).

The report by Eamonn Duff in the Sun Herald (11 April 2010) is quoted here at length as it throws light on each of the earlier cases. The ethnicity of the contractor in this case has not been specified and in fact it barely matters. The issue here is the power exerted by a man in this role over any casual contract worker:

Rashmika Patel had arrived in Australia with her husband, Vishnu, in 2005. Directed by Immigration Officers to Griffith, the couple had started work on a farm at a nearby town under a contractor who supplied a stream of migrant workers. The majority were Hindispeaking couples and, as a condition of employment, they were required to live with up to 10 other workers in one-bedroom houses which the contractor owned - the rent for which was deducted automatically from their wage.

Mrs Patel gave a statement to police in May 2007 saying she had been raped at her workplace but it took seven months before the interviewing officer spoke with her alleged attacker. It then took so long for police to pass the case onto the Director of Prosecutions that the case collapsed. Once Mrs Patel complained, she and her husband were sacked, leaving her to beg on the streets.

Mrs Patel refused to give up, taking a case to the Victims Compensation Tribunal which ruled in 2010 that "on the balance of probabilities", Mrs Patel was the victim of "indecent assaults and instances of unlawful sexual intercourse".

The 44-year-old was awarded substantial damages under the Victims Support and Rehabilitation Act, paving the way for her to pursue other civil claims.

Mrs Patel, speaking through an interpreter from a friend's house near the NSW-Victoria border, said the tribunal ruling was a relief: "I went to the police because people said that in 
this country they support women in these cases. That never happened for me but I am grateful there were others who didn't let this disappear."

Mrs Patel's supporters included a lawyer, Dale Brooks, who said her "extraordinary tale" highlighted how poorly non-English speaking migrant workers were regarded, particularly in rural Australia.

"The NSW Police, Australian Federal Police, Immigration Department ... none of them were interested because it was all too difficult," he said. "It took an incredible amount of pressing and probing for them to finally accept that something was wrong."

"Some employers treat these Indian people as galley slaves, as economic units: pick crops, get out. If someone has an injury or is exploited they couldn't care less - move them on and get someone else in. It's entirely unregulated.”

"Most Indians who are exploited return home. What makes this case so unique is that Rashmika not only stayed on and fought, she won."

Alerted by Mrs Patel's lawyer, the Sun Herald journalist investigated the contractor's history and found that he had been the subject of four separate complaints of sexual abuse. In 2002 three women had instigated legal proceedings alleging sexual harassment. The owners of the farm and the contractor had apparently settled with the women 'out of court', without admitting liability, paying them $\$ 8000$ each. Then in 2004 another Indian worker told police that the contractor had sexually assaulted her. The case apparently failed. As Eamonn Duff continued:

Mrs Patel's fight for justice had come at a personal cost. Her lawyer, Dale Brooks, explained: "In India there's huge shame attached to this stuff on a cultural level. Someone, rather maliciously, sent details of her plight back to her homeland."

These three stories demonstrate that the vulnerability of Indian workers extends beyond the cities - and that the conditions of contract labour in much of rural Australia makes already vulnerable workers even more vulnerable to exploitation and abuse. It is clear that this involves more than the actual enrolled students themselves but also involves the family members who often come with them. Australian educational providers must recognise that South Asian students are unlikely to fit the stereotypical single young Australian living at home with parents or in a share house, the kind of person whom they have grown used to undertaking an undergraduate or professional qualification. 
The agricultural setting also demonstrates that the vulnerabilities of Indian students and their families are shared with all of those from South Asia - such as Sri Lankans and Bangladeshis - who are less likely to be able to access substantial family resources from their homeland than middle class East Asian students may be. Furthermore, the uncertainties of the student visa arrangements are closely related to the uncertainties of the 457 visas held by temporary workers, who have often found the conditions they were expecting were significantly different from those they actually faced on arrival and yet found very little support to challenge (Saulwick 2010). All of these circumstances mean that the power of contractors over workers is enormously amplified. Whether or not they are of the same ethnic group as the workers, the contractors are exercising unlimited control over vulnerable workers and, even though unions like the AWU and, in the city, United Voice, are attempting to intervene on behalf of those workers, the disinterest or outright hostility of police has led to frustration and further harm.

This is not a situation in which it is only South Asians whose labour has been managed through the contract system in rural industries. It is not surprising however that the other workers characteristically involved in contracts have also been already made vulnerable by racial and ethnic discrimination. Some examples of other people who have been drawn into contract gangs suggest more of the benefits to agriculturalists.

One group has been Aboriginal cotton chippers in the North West of NSW. They had suffered extensive exploitation by contractors and cotton farmers since irrigated cotton expanded in the 1960s. Yet they found they had little support from the AWU until they organised among themselves and held their own strike in the summer early in 1972. Their grievances reveal similar low pay, poor or non-existent housing, dangerous work conditions and no job security as South Asians experience today in both rural and urban contracts. The memories of Aboriginal people who experienced the Wee Waa cotton fields in the 1970s add another dimension to the picture of contract work. As Isabel Flick (2004) explained, the 'boss' was very personal and could not be avoided. The contractors she remembered were right there on top of everyone all the time, carting workers around from job to job, encouraging them - or standing over them - to get them to start and then abusing them if they didn't pick their quota or meet the farmer's deadline. They delivered tightly controlled and compliant workers to what was then very much a red-neck new industry. In search of elusive profits, cotton growers in the 1970s took chances with pesticides and herbicides to the frequent cost 
of sprayed workers and the river environments, where fish kills became common signs that the cotton farm dams were overflowing.

Even earlier, in the 1870s when the NSW gold rush had passed, rural Chinese workers were managed as contracted gangs to clear land in grazing areas in north western NSW.

Disparagingly known as 'stick pickers', these men did the heavy work of felling and moving the timber off vast acreages of land. Often with Chinese contractors, the all-male gangs moved across the landscape, conveniently - for the Anglo settlers - forever rootless and transient. So the contract gang has offered a way to extract labour without offering any of the real social costs of housing, education and participation in local community.

The problem lies therefore not only in the specific racialised vulnerability and hostility faced by South Asians today or by Aboriginal or Chinese workers at other times. In each case described here, whether in urban or rural settings, a significant element has been the structure of power relations arising through the contract method of managing labour. The conditions of contract labour have in each case delivered benefits to employers and industry at the cost of worsening the vulnerability of the contract workers.

\section{References}

ABC News 30 Sept 2009, available at: http://www.abc.net.au/news/2009-09-30/videofootage-examined-in-search-for-missing-man/1084714 accessed 1 November 2015.

ABC News 27th February 2010, available at: http://www.abc.net.au/news/2010-02-27/policeprobe-indian-fruit-pickers-murder/344788 accessed 1 November

ABC News 15th March 2012, available at: http://www.abc.net.au/news/2012-03-15/murderinquest-told-of-marriage-snub/3891930/?site=milduraswanhill accessed 1 November 2015.

ABC News, 1 Aug 2012, available at: http://www.abc.net.au/news/2012-08-01/griffithmurder-not-guilty-verdict/4169576 accessed 1 November 2015.

ABC PM, 8 January, 2010, available at: http://www.abc.net.au/pm/content/2010/s2788577.htm?site=riverina accessed 1 November 2015.

ABC Riverina, 5 January, 2010, available at: http://www.abc.net.au/news/stories/2010/01/05/2786139.htm?site=riverina accessed 1 November 2015.

Australian Census 2001 Demographic Map New South Wales by POA - BCP field 2775 Hinduism Persons 
https://commons.wikimedia.org/wiki/File:Australian_Census_2011_demographic_map _-_New_South_Wales_by_POA_-_BCP_field_2775_Hinduism_Persons.svg

Ahuja, R. 2006, 'Mobility and containment: the voyages of Indian seamen, c. 1900-1960', International Review of Social History, vol. 51, p111-141. doi: http://dx.doi.org/10.1017/S002085900600263X

Balachandran, G. 2012, Globalizing labour? : Indian seafarers and world shipping, c.18701945, Oxford University Press, New Delhi.

Broeze, F.1991, 'The muscles of empire - Indian seamen and the Raj 1919 - 1939', Indian Economic and Social History Review, vol.1, pp 43-67.

Duff, 2010, 'Fruit picker wins fight against sex abuse', Sun Herald, 11 April 2010, available at: http://www.smh.com.au/nsw/fruit-picker-wins-fight-against-sex-abuse-20100410rzug.html accessed 1 November 2015.

Flick, I. and Goodall, H. Isabel Flick: the many lives of an extraordinary Aboriginal women, Allen and Unwin, Crows Nest, 2004, pp 113-118

Herde, E. and Lower, T. 2013, 'Farm related injuries reported in the Australian print media 2012', Australian Centre for Agricultural Health and Safety, University of Sydney, available at:

http://www.aghealth.org.au/tinymce_fm/uploaded/Research\%20Reports/farm_related_i njuries_2012_report_final.pdf accessed 1 November 2015.

International Labour Organisation OH\&S Standards: http://www.ilo.org/safework/cis/industries-sectors/WCMS_219011/lang--en/index.htm; This ILO site is a set of links of the International Labour Standards from 1981-1985 which are used in Australia to provide OH\&S standards for 'service sectors', including cleaning industries and many other casualised occupations. Further documents lay out guidelines (2001) on prevention of bullying, violence and other health-related OH\&S standards for such occupations, at http://www.ilo.org/safework/areasofwork/workplacehealth-promotion-and-well-being/WCMS_108511/lang--en/index.htm

Rediker, M. 2007, The Slave Ship, Viking, Penguin,

Rolls, E. 1992, Sojourners University of Queensland Press, St Lucia, 1992.

Rolls, E. 1998, Citizens: the epic story of China's centuries-old relationship with Australia: flowers and the wide sea, University of Queensland Press, St Lucia.

Saulwick, J. 2010, 'Till marriage and sacking us do part', Sydney Morning Herald, 5 Feb 2010, available at: http://www.smh.com.au/national/till-marriage-and-sacking-us-dopart-20100204-ngan.html accessed 1 November 2015.

United Voice 2013, A Dirty Business: The Exploitation of International Students in Melbourne's Office Cleaning Industry, a research publication by the Clean Start: a fair deal for cleaners campaign available at: http://www.unitedvoice.org.au/documents/dirty-business-the-exploitation-internationalstudents-melbourne's-office-cleaning accessed 1 November 2015.

Weaver , H. 2009, 'The colonial context of violence reflections on violence in the lives of Native American women', Journal of Interpersonal Violence, vol. 24, no. 9, pp. 15521563. doi: http://dx.doi.org/10.1177/0886260508323665 